Arab World English Journal (AWEJ) Special Issue on Covid 19 Challenges April 2021

DOI: https://dx.doi.org/10.24093/awej/covid.19

Pp.244-263

\title{
The Development of Intercultural Competence of Secondary School Pupils and University
} Students

\author{
Kateryna V. Krotik \\ The Faculty of Foreign Languages \\ State Institution «South Ukrainian National Pedagogical University \\ named after K. D. Ushynsky,» Odesa, Ukraine \\ Oleksandra O. Morhun \\ The Department of Pedagogy \\ State Institution «South Ukrainian National Pedagogical University \\ named after K. D. Ushynsky,» Odesa, Ukraine \\ Correspoding Author: morhun.alekssa@gmail.com
}

Recieved: $12 / 30 / 2020$

Accepted: $3 / 14 / 2021$

Published: 4/26/2021

\begin{abstract}
Some issues regarding how secondary school pupils' and university students' (majoring in English, Chinese) intercultural competence, which are to be developed under conditions of the coronavirus pandemic COVID-19, are presented in the article. The authors review the literature on the education standards alongside some native and foreign scholars' definitions of the pedagogical phenomenon "competence." The purpose of the study is to analyze the model of competence under focus. We introduce some learning objectives aimed at developing secondary school pupils' and university students' intercultural competence. The problem's relevance is preconditioned by the expanded intercultural and interethnic ties within Ukraine and other countries, which are to be observed when dealing with representatives of different countries and considered when elaborating the competence-based framework for secondary school pupils and university students. The leading suggestions (findings) related to the study have been given: systematic formation of the intercultural competence of secondary school pupils and university students, improvement of the existing curricula, and syllabi's adaptation of the educational profession-oriented training programs intended future translators and teachers of foreign languages.

Keywords: intercultural competence, education normative education, training models, methodological mode, Covid-19, secondary pupils, university students.

Cite as: Krotik, K.V., \& Morhun, O.O. (2021). The Development of Intercultural Competence of Secondary School Pupils and University Students . Arab World English Journal (AWEJ) Special Issue on Covid 19 Challenges (1) 244-263. DOI: https://dx.doi.org/10.24093/awej/covid.19
\end{abstract}




\section{Arab World English Journal (AWEJ) Special Issue on Covid 19 Challenges April 2021}

\section{Introduction}

We substantiate the need to modernize the formation of the lingua cultural competence for secondary school pupils and university students'. In these terms of their readiness for situational intercultural communication (in a foreign language) in any situation and on any topic, we will offer some methods to be followed. In this view, the authors analyze methodological literature to distinguish some aspects that have not been considered before in detail. We used adequate methods during the educational process. Some assignments related to practical methodological work, which effectively contribute to the formation and development of the lingua cultural competence of educational process participants, were described.

Linguistic and cultural competence acquires particular importance exactly in high school when high school pupils need to communicate with foreigners, which generates their motivation to use both linguistic and culture-centered potential in the context of cross-communication. Many scientists such as teachers, methodologists, psychologists, and even psychotherapists have studied the problem of forming the lingua cultural competence of high school pupils.

The analysis of the scientists' work allows us to conclude that "lingua cultural competence" is a new concept. It takes its origin from the term "socio-cultural competence" as the readiness and ability of high school pupils to perform situational intercultural (Englishspeaking) communication. In our opinion, there exists an infinite potential of tools to improve the educational process in our problems. We would like to emphasize that in our study, the term "lingua cultural competence," "linguistic and cultural competence," "intercultural competence," and "cross-cultural competence" are considered to be synonymous.

It is essential to approach the development of high school pupils' lingua cultural competence through the methodology of teaching English and Chinese as the keynote elements. We are to consider several aspects, which, in our opinion, are dictated by the modern dynamic development of innovative integrated training, which seems to be significant and determines the effectiveness of training learners. Other factors to be taken into account are peculiarities of learners' information perception (represented system) and their age (age-related leading needs).

On the one hand, after graduating from secondary general education schools, graduates enter universities to acquire their future professions. After graduating from a higher education institution, certified specialists perform their professional duties at the state level and in the international format. In other words, the knowledge of a foreign language alongside the cultural heritage of the country in which a specialist works is a necessary component of his (her) job professional diagram.

On the other hand, in the era of globalization and interdependence of countries in economics, international trade, and politics with the aspiration to save and demonstrate their individuality, the national language is the primary vector of the realization of these processes. Therefore, the topic's relevance regarding teaching theory and translation methods, interlanguage, and intercultural communication are still under scholars' focus to ensure successful negotiations. It is known that the English language is an international language of communication that connects representatives of different cultures in various areas of cooperation. However, with the global implementation of 


\section{Arab World English Journal (AWEJ) Special Issue on Covid 19 Challenges April 2021}

International projects initiated by the Government of China ("One Belt - One Road," "New Silk Road") are globally implemented. Therefore, the status of the Chinese language is very high. The number of those who want to study the Chinese language and culture and to work in Chinese companies is increasing. In this regard, the main questions cover the content of methodological support for the process aimed at developing lingua cultural competence of future sinologists (philologists, translators, Sinologists). Also need to take into account the lack of a sufficient number of methodological materials for effective teaching/learning of a foreign language at universities. The second problem is the COVID-2019 pandemic, which forces foreign language teachers and pupils/students to work remotely; it generates particular difficulties.

\section{Literature Review}

This paper aims at analyzing the normative and theoretical-methodological literature and presenting a model of teaching a foreign language (English and Chinese) that takes into account the Common European Framework of Reference for Languages: Learning, Teaching, Assessment and the basic requirements of the NUS concept (The New Ukrainian School). It can resolve the contradictions between the rapid technical and technological development of the world and a gradual decline of an individual's lingua cultural competence.

The standardized literature review on the indicated problem showed that under the term "competence," we could understand the scope of knowledge, skills, and experience gained in the training process. In the spectrum of this study, "competence" correlates with the content of the above meaning "profession-oriented pedagogical training" alongside the sense represented in the Law of Ukraine "On higher education" dated 05.09.2017 No. 2145-VIII. It presupposes acquiring qualifications in the relevant areas of training or specialty. The activity of future translators of English/Chinese is carried out in higher educational institutions, thus, according to the Resolution of the Cabinet of Ministers of Ukraine (2017). We would like to emphasize that in our study, these concepts are considered to be synonymous: "translator of the Chinese language," "translation specialist," "translator-sinologist," and "translator-orientalist."

We also intend to consider some features of teaching English/Chinese at high school and the peculiarities of training future translators. Next, to analyze and study the existing (in Ukrainian and foreign education space) functions and approaches the distance teaching/learning process facilitating the development of secondary school pupils' and university students' intercultural competence within a pandemic situation.

For the realization of these aims, we have processed and analyzed the education-related documents as follows:

- the Law of Ukraine "on Education" (The Law on Education, 2017);

- the Law of Ukraine "on Higher Education" (The Law on Higher Education 2019);

- Common European Framework of Reference for Languages: Learning, Teaching, Assessment

- The NUS (New Ukrainian School) concept (Kontseptsiia Nush, n.d.);

- The Decree of the President of Ukraine "On the National Doctrine of the Development of Education";

- "Foreign language teaching programs for general education institutions and specialized schools with in-depth study of foreign languages: grades five-nine (English, German, French, Spanish)" 


\section{Arab World English Journal (AWEJ) Special Issue on Covid 19 Challenges April 2021}

(Foreign language curricula for secondary schools and specialized schools with in-depth study of foreign languages Grades five-nine: English, German, French, Spanish, 2017);

- The manual "Recommends on Organizing Distance Learning";

- Educational and profession-oriented programs for the training of the future philologiststranslators.

The above scientific and pedagogical literature allowed us to obtain a more in-depth and better understanding of linguistic and cultural competence, which is to be mastered by high school pupils and future translators. We considered a necessary complex of external and internal circumstances aimed to raise the effectiveness of educating activities under pedagogical conditions.

The multidimensional focus of the teaching and upbringing of secondary school pupils and university students covers a particular spectrum of competences. It contributes to the clarification, updating, and adaptation of the professional training contents targeted to the contents of the curricula and syllabi of each discipline (at the designated educational level) and pupils' learning outcomes. However, the approach to defining the concept of "competence" appears to be ambiguous for foreign and domestic scholars. Let us consider the essence of the concept "competence" represented in primary sources.

In 2001, the International Board of Standards for Training, Performance, and Instruction (IBSTPI) proposed the initial definition of "competence" as "the ability to carry out activities expertly, to perform tasks or work according to certain criteria" (Spector, 2001), according to the acquired knowledge, skills, and educational achievements, to be more precise.

The experts from the European Union interpret the phenomenon "competence" as actually achieved learning outcomes. It is validated through the ability of the learner autonomously to apply knowledge and skills in practice, in society, and at work. (Deseco, 2002).

The authors of the United Nations Development Programme (UNDP) "Education policy and education "equal to equal," interpret competence as "an integrated characteristic of person's quality, a resultative unit formed through experience, knowledge, skills, attitudes, behavioral responses" (Ovcharyk, 2004, p.95).

The representatives of the Federal Statistics Department of Switzerland and the National Centre for Educational Statistics of the United States and Canada (Salganik, Rychen, Moser, Konstant) contributed to defining the concept "competence" by launching the program "Definition and selection of competencies: theoretical and conceptual foundations" in 1997. Experts from various fields made a significant attempt to systematize and generalize the experience of many countries in the framework of the designated program. They gave the most compact definition of "competency," being more than just knowledge and skills, as the ability to 


\section{Arab World English Journal (AWEJ) Special Issue on Covid 19 Challenges April 2021}

successfully meet complex demands by drawing on and mobilizing psychosocial resources (including skills and attitudes) in a particular context [the same source].

We should remark that despite, at first glance, a clear understanding of the concepts under study, some scientists Bolotov, Lednev, Nikandrov, Ryzhakov, Raven, and others, year of publication) equate the concepts "competence" and "competency" in these semantic markers: "knowledge," "abilities," "skills," "awareness," etc. (Bolotov \& Lednev, 2003) On the other hand, the synonymy or likeness of "competence" and "competency" is caused by the etymology of these words (English competencelcompetency, Latin competentia) and their incorrect translation into Ukrainian/Russian.

Many foreign (Armstrong (2004,) Woodruff (1991,) Garfinkel (2017,) Zimnyaya (2003,) Rychen (2004,) Tiana (2004,) Khutorskaya (2003,) et) and domestic scholars (Bogush (2008,) Bibik (2005,) Vashchenko (2019,) Ermakov (2005,) Ovcharuk (2003,) Pometun (2005,) Popova (2016,) and others) studied the competence content, structure, functions alongside the means and areas of its implementation. Let us analyze the author's definitions of the pedagogical phenomenon "competence."

Rychen and Tiana interpret the notion "competence" as a combination of interrelated cognitive and practical skills, knowledge (including tacit knowledge), motivation, values and ethics, attitudes, emotions, and other social and behavioral components that together can be mobilized for effective action in a particular context (Rychen \& Tiana, 2004).

Pometun (2005) associates competence with a broad concept that encompasses cognitive, operational-technological, motivational, ethical, social, and behavioral components; contains learning outcomes (knowledge and skills), a system of value orientations (Ovcharyk, 2003, p.61).

In Khutorskoy's opinion, competence implies "the acquisition of a certain amount of knowledge and experience by a person that enables him/her to conclude something, convincingly express their his/her thoughts, to act adequately in different situations" (Khutorskyi, 2003, p.61).

Zimnyaya interprets competence as an actual manifestation of competency, as intellectually and personally-driven experience of a person's socio-professional activity, as knowledge based on which a person can use competences (Zymnia, 2003).

Bogush believes that the concept of "competence" is a complex feature of an individual that combines the results of the previous mental development (Bogush, 2008, p.56).

Popova defines the concept "competence" as a "qualitative-measuring characteristic of an individual, integrated result of the successful transformation of normatively defined knowledge 


\section{Arab World English Journal (AWEJ) Special Issue on Covid 19 Challenges April 2021}

being acquired, skills and abilities into a professional activity. That is, the formation of a person's ability to act in practice successfully, using the acquired educational and life experience in a profession-related or other activities. The result of gaining competence - assimilation of educational, subject-oriented and professional (conceptual and professional) competences" (Popova, 2016).

According to theoretical sources, competence covers various levels of these spheres: cognitive, social, family-life, professional and personal and correlates with such concepts as "personality," "characteristic," "quality," "ability," "capability," "awareness," "knowledge," "skill" and "competency." In the light of the preceding, competence is understood as the person's evaluative and productive integrated characteristic, which is manifested at the end of the training, special training through the acquired knowledge, skills, and experience alongside the ability to use them in practice.

\section{Methods}

The appropriate research methods have been considered: the theoretical analysis of the abovementioned normative documents; psychological, pedagogical, and methodological literature generalize modern innovative integrated methodological approaches to the development of the lingua cultural (English and Chinese) competence of high school pupils and Bachelor-students. The modeling of the process enabled the formation of the competence under study. We determined these leading essential components contributing to the development of the competence under focus: modern pedagogical, psychological, and methodological innovative integrated principles of education organization; partnership pedagogy; child (student) - centrism; positive, age-related and cognitive psychology; competence- and activity-based approaches; integrated "subject-language" learning principle (Figure one) and the principle of continuous learning, in particular in the context of the coronavirus pandemic COVID-19 [14].

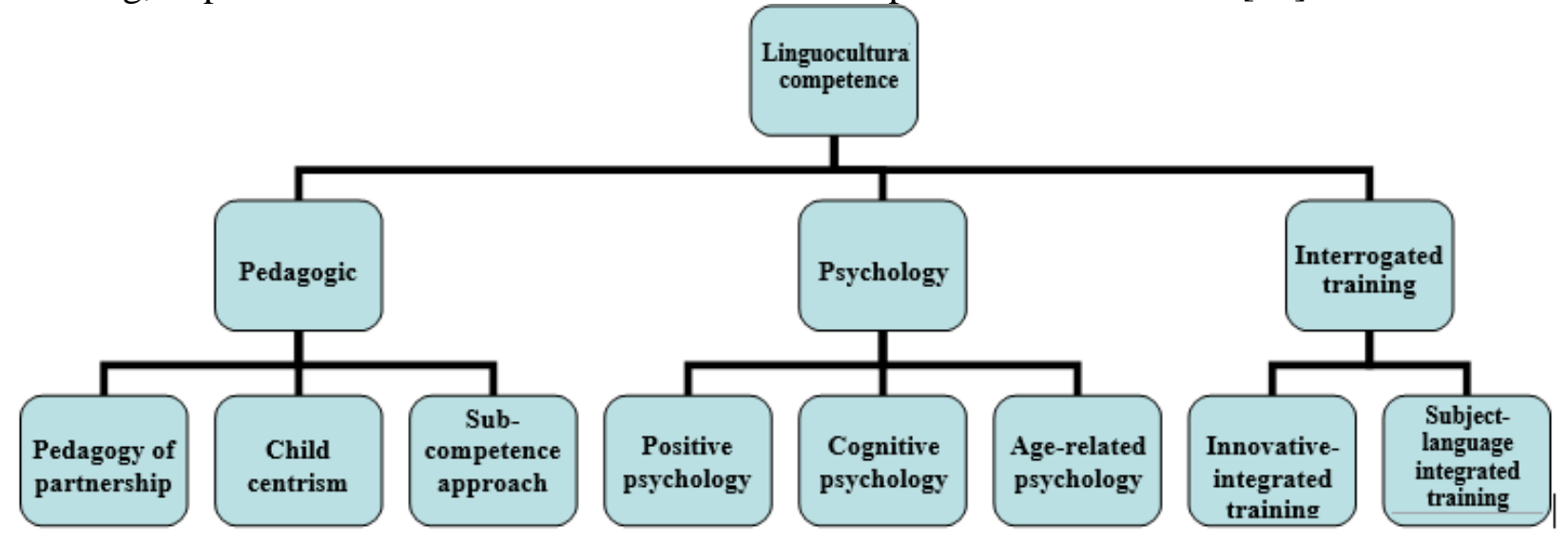

Figure one. The model of the lingua cultural (intercultural) competence development.

\section{Findings}

"The new Ukrainian school is a key reform of the Ministry of Education and Science. Its main aim is to create a school that will be pleasant to study at and equip pupils not only with knowledge but also with the ability to apply it in everyday life. The teaching is a person who provides a reform. Without teachers or reform, any changes will be impossible. That's why the 


\section{Arab World English Journal (AWEJ) Special Issue on Covid 19 Challenges April 2021}

main principle of the NUS (The New Ukrainian School) is a motivated teacher." (Kontseptsiia Nush, n.d.). "The primary function of a teacher is to support a pupil in his/her activities: to promote his/her successful progress in the flow of educational data, to facilitate the solution of emerging problems, to help to assimilate a large amount of a variety of integrated information, to realize his/her abilities, his/her personal qualities, to provide support for the pupil's need for selfdevelopment with the self-improvement process.

Due to this in the world, the educational community began to use a new term, which emphasizes the importance of teachers' function - facilitator - (that's one who promotes, facilitates, helps to learn)» (Kontseptsiia NUS (The New Ukrainian School), n.d.). This function is also continued to be performed by lecturers, where the future specialists are trained in various fields, including future philologists. The quarantine has complicated the process of language training of a person in comprehensive school and higher education. Considering the above, we propose a universal model of the formation of lingua cultural competence of complete school pupils and university students in Ukraine.

The methodology that we have elaborated consists of these ways: the organization of the theoretical, practical, and integrated activities intended for the participants of the educational process in terms of education competence, which is the main requirement of the NUS (The New Ukrainian School) Concept and the Common European Framework of Reference for Languages (Kontseptsiia NUS, n.d.)

Our methodological approach is based primarily on such postulates as: philosophy of the child (students)-centrism, pedagogy of partnership, positive, age-related and cognitive psychology, sub-competence-based approach, innovative-integrated principles of the educational process, and the principle of learning continuity.

The choice of the above postulates is due to the requirements of the modern NUS (The New Ukrainian School) Concept and the All European Framework of Reference for Language Education (Kontseptsiia NUS, n.d.)

By the phenomenon of "child (student)-centrism," we mean the provision of the upbringing process and education of each child (each student) based on the development of his (her) natural abilities," according to Zakharenko (1997). The pupil/student is the center of the educational process. The main thing in the educational process is focusing on the pupil's / student's needs, child (students)-centrism" (Kvas, 2011). A person (personality)-oriented model of education that is based on the ideas of the child (students)-centrism, is aimed at approaching maximally to pupils'students' personality, abilities, and life experience, providing moral and psychological comfort within the process of teaching and bringing them up.

"Pedagogy of partnership, or cooperation, based on the principles of humanism; dialogical subject-subject interaction between all participants in the educational process (pupil - school society - family; student - university - society - family); a creative approach to the development of each personality; mutual understanding; support; conscious person's responsibility for his/her results; distributed leadership" (Bekh, 2000, p. 33). 
Arab World English Journal (AWEJ) Special Issue on Covid 19 Challenges April 2021

To ensure the moral and psychological comfort of senior pupils and first and second-year bachelor course students under conditions of the coronavirus pandemic, we follow positive, agerelated (developmental), and cognitive psychology.

Positive psychology — is a branch of psychology focused on the positive aspects of the human psyche. In contrast to the orientation of classical science to psychological problems and pathology, the main research topics in this field are as follows: happiness, optimism, flow, trust, forgiving, and solidarity. This research area attempts to make the experience of human life more satisfying and to uncover natural abilities (Positive psychology, despite complicated situations.

Age-related a person's (Developmental) psychology is a branch of psychological science. We study the features of a person's mental and personal development at different life stages (Developmental psychology). Therefore, a platform for teaching a foreign language to pupils and students transformed in the context of quarantine.

Cognitive psychology (lat. Cognitio "knowledge") is a field of psychology that investigates cognitive processes, such as problem-solving, memory, and language processes (Cognitive Psychology). Pupils and students experienced the positive and negative aspects of learning foreign languages and cultures of the countries, and the wording is being studied in the onlinemode.

Considering the importance of formally dynamic individual and age characteristics of the pupils' (students') personality, we believe the distance conditions for learning. It was experimentally proved that the following four types of pupils (students) were distinguished: visuals, audile (auditory learner), kinesthetic, and digital. While developing a methodology for individual and group types of online work, we considered the empirical results of our study, age features of senior pupils and first-year/second-year students of bachelor courses (as the leading need for communication with peers) (Bulakh, 2016). According to our methodology, students will work in micro-groups of three or four people representing different types according to the corresponding representative system and specific functional role content component. We do not name the subjects of learning by their kind of the leading channel of information perception, but by number: the first subject of learning is visual, the second subject of education is digital, and the third is audial, etc. (Krotik, 2020).

During the educational process, several necessary competences that correspond to the modern concept of language education are developed: speech, socio-cultural linguistic, language (linguistic), and educational-strategic (Nikolaieva, 2013). The idea of "socio-cultural competence" is being worked out in scientific publications of these scientists: Borisko (1997,) Galskova (2004,) Zimnya (2005,) Kozhedub (2016,) Kuzmenko (2007,) Nikolaieva (2013,) Pisanko (2008,) Rudakova (2017,) Safonova (1996,) Tarnopolsky (2004,) Ter-Minasova (2000.) They consider this competence as one of the leading indicators of the readiness of a participant in the educational process to implement intercultural communication.

\section{Results and Discussion}

"Sociocultural competence" is defined as the ability of an individual to obtain various cultural, linguistic, cultural, socio-cultural, and intercultural integrated knowledge. A person needs it to achieve goals in foreign language communication. Summarizing the above, we chose modern 


\section{Arab World English Journal (AWEJ) Special Issue on Covid 19 Challenges April 2021}

and trendy topics for the English and Chinese classes. "The training program of foreign languages" corresponds to the specific tasks and requirements of the NUS (The New Ukrainian School) Concept aimed at developing pupils' (intercultural) lingua cultural competence alongside educational and profession-related programs for the students majoring in 035 "Philology." We also used some elements of integrated training, according to the requirements of the NUS concept, "On the National Doctrine of the Development of Education," and the Standards of Higher Education in Ukraine.

According to "Foreign language teaching programs for general education institutions and specialized schools with in-depth study of foreign languages: grades five-nine (English, German, French, Spanish" (The program is registered by order of the Ministry of Education and Science of Ukraine dated 07.06.2017 № 804). The following topics of situational communication have been identified and expanded. They cover national and cultural specifics of speech activity, form senior pupils' ability to use elements of the socio-cultural context that is necessary for intercultural communication with native speakers, to be more precise:

- I, my family, my friends (family ties, daily routine, appearance, character traits, family responsibilities, family traditions, autobiography).

- Clothes, food, drinks (shopping, visiting stores, food traditions, the leading assortment of goods, price, money, clothes sizes, names of dishes, cooking, table setting, kitchen appliances, utensils).

- Recreation and leisure (hobbies, free time, vacations, sports, Olympic Games, cinema and theater, sportspeople, sports competitions, clubs, sections).

- Nature. Weather. Travel (general information about Great Britain, Ukraine, transport, luggage items, travel documents, sights of capitals).

- Native city. Village. Holidays and traditions. School life (subjects, working day, English and Ukrainian lessons, activities in the classroom, favorite subject, extra-curricular activities, types of schools, teaching staff, grading system, rules of behavior).

- Health care (doctor's visit; symptoms of diseases, medical institutions, medical workers, medicines).

- Lifestyle (healthy lifestyle, entertainment, Pen Pals, active recreation).

- School library (selection of books to read, favorite writer, readers, literary hero, literary genres, work with the electronic library).

- Mass media (press, columns, television and radio, programs, presenters, favorite radio/television show).

- Music (musical styles, genres, composers, musicians, performers, instruments, concert attendance).

Great Britain and Ukraine (geographical location, geographical concepts, types of landscapes, climate, population).

- Youth culture (appearance, hobbies, youth organizations, clubs, camps, currents of youth culture).

- Science and technological progress (famous scientists, inventors, and inventions).

- Work and profession (professions, career choice, characteristics of occupations, factors influencing career choice) (Foreign language curricula for secondary schools and specialized 


\section{Arab World English Journal (AWEJ) Special Issue on Covid 19 Challenges April 2021}

The Development of Intercultural Competence of Secondary School

Krotik \& Morhun

schools with in-depth study of foreign languages Grades five-nine: English, German, French, Spanish).

"The level of knowledge of a foreign language at the end of the ninth grade should correspond to the level of A2 + following "The Common European Framework of Reference for Languages: Learning, Teaching, Assessment" (Pan-European Recommendations for Language Education: Study, Teaching, Assessment). The topics mentioned were widened for first- and second-year students majoring/minoring in Chinese translation. We substituted the English culture-related issues with the Chinese ones: China and Ukraine, Science and technological progress: Chinese dimension, Travelling in China, etc.

The rapid development of the latest information technologies and their implementation around the world significantly affect the development of the personality of the modern pupil. Therefore, the current educational institutions aim provide the academic results that would contribute to the development of competence components of the individual in various fields of activity and correspond to the modern requirements of our society.

The standard of higher education in the specialty 035 "Philology" (Program is registered by the order of the Ministry of Education and Science of Ukraine dated 20.06.2019 № 869) reveals special (profession-related, subject-centered) competences, namely: the ability to use the knowledge about the language as a unique sign system, its nature, functions, levels in professionrelated activities; the ability to freely, successfully and effectively use the studied language (s), in oral and written forms, in different genre/style varieties and registers of communication (official, non-official, neutral), for solving communicative tasks in various spheres of life; the ability to conduct situational communication, which covers the national-cultural specifics of speech activity; to form university students' ability to use elements of the socio-cultural context; the ability to freely operate with unique terminology, to solve professional problems; the ability to realize the linguistic, literary and special philological (it is depend on the chosen specialization) analysis of texts belonging to different styles and genres, etc.

The system for ensuring the quality of educational activities and the quality of higher education by an institution of higher education (system of internal quality assurance), upon the proposal of the institution of higher education, is assessed by the National Agency for Quality Assurance in Higher Education or independent institutions accredited by it for evaluating and ensuring the quality of higher education for its compliance with the requirements for the system of ensuring the quality of higher education are approved by the National Agency for Quality Assurance in Higher Education, and international standards and guidelines for quality assurance in higher education.

During the topic analysis of situational communication, which covers the national and cultural specifics of learners' speech activity, we concluded that the rational use of the principles of integrated learning in our methodology effectively contributes to the formation and development of the (intercultural) lingua cultural competence of secondary school pupils and university students. That is an essential component in achieving the set task, namely, in modernizing the formation of their lingua cultural competence under conditions of the 


\section{Arab World English Journal (AWEJ) Special Issue on Covid 19 Challenges April 2021}

The Development of Intercultural Competence of Secondary School

Krotik \& Morhun

coronavirus pandemic in terms of their readiness for situational intercultural (English and Chinese) communication situation and on any topic.

The term "integration" began to be actively used only in the 19th century when relations were formed between previously isolated branches of knowledge. By the integration, we understand the uniting of parts, elements, and components that once existed separately into a single whole by complicating and strengthening the connections between them (Proshkin, 2010).

The term "integration" is quite multifaceted and includes changes, which can occur at different levels. However, the formation of unity between separate elements by identifying their standard features is familiar to any integration process is scholars. These degrees of integration: distinguish subject-center (between objects of research or complex problems), problem-related (between research methods), horizontal (in natural sciences), and vertical (between groups of sciences) integration (Ivanchyuk, 2016). We consider innovation-integrated and subject-language integrated training in the quarantine context in our methodology.

The specificity of the integrated learning methodology is that it creates favorable conditions for the manifestation and development of the teacher's creativity; provides absolute freedom to choose a topic, content, tools to be used during the educational process.

We propose the methodology that involves integrated learning by using innovative technologies in the specified online context - first of all, and this is the technical side of the developed method, namely, the use of modern teaching tools such as:

- Methodological recommendations for teachers: how to use the technique (non-printed and electronic forms);

- A workbook for each student (non-printed and electronic form);

- Presentations of the lessons on each topic in PowerPoint (in electronic format).

During the introduction of integrated online learning, it becomes possible not only to provide but also develop and improve knowledge, skills, and abilities in a foreign language and show pupils (students) the environment in all its diversity involving the knowledge from different academic disciplines, for example Literature, Art, Basics of life safety, Lingua cultural studies, General Linguistics, which contributed to the emotional development of the individual, the formation of her (his) creative thinking and critical competences provided by the NUS Concept, "The training program of foreign languages" and higher education standards.

The use of an innovatively integrated method allows us to make the educational process one-toone interesting for the participants of the teaching/learning process without reducing the program requirements; to optimize it by restructuring the content of training and practical alternatives to traditional forms of exercise, namely: Microsoft Teams (Microsoft 365), ZOOM Cloud Meetings, WeChat, DingTalk, Google Meet and the formation of the intercultural/lingua cultural competence of learners under the conditions of COVID-19.

Firstly, it is necessary to understand what lies in the content of the concept "distance learning." We will try to explain it.

Distance learning is a form of education using computer and telecommunication technologies that provide interactive interaction between teachers and pupils/students at different training and self-guided work with information network materials. 
Arab World English Journal (AWEJ) Special Issue on Covid 19 Challenges April 2021

The Development of Intercultural Competence of Secondary School

Distance learning and technology can be viewed as a natural process of development. It is accompanied by a change in traditional forms and training methods due to the intensification of computerized procedures.

A striking example is replacing a blackboard with chalk with interactive panels for training and presentations and various computer-assisted systems; a transition from an electronic library, Krotik \& Morhun from a class with headphones to modern language laboratories with the high-speed Internet.

Professor Haifa Al-Nofaie, in the article, surveys of pupils and students on computer ownership, provides background information on the level of students' readiness to learn on the Internet and also surveys technical problems in distance learning. Due to this survey, we can assess the situation and find solutions for solving problems that negatively affect sound and practical knowledge. (Al-Nofaie, 2020)

The technology of subject-language integrated learning has been introduced in many European countries. The term "subject-language integrated learning" was created by Marsh in 1994. The author first described this methodological approach, in which the study of a foreign language is integrated. "The methods of subject-language integrated learning refers to situations where subjects or parts of them are studied in a foreign language with a dual purpose. It is namely - the study of content while learning a foreign language" (Content and Language Integrated Learning (CLIL) at School in Europe). In our opinion, it is regardless of the learning conditions (online, offline or mixed).

The technology of the subject-language integrated learning meets the requirements of didactic presupposes enabling the development of the pupils'/students' linguistic and communicative competences in English and Chinese. In our case, the intercultural/lingua cultural (English and Chinese) competences learning in the educational context where their general education-related knowledge, skills, and abilities are formed and developed. While developing the methods and planning the training sessions, we took (as a basis) the four main components of the " $4 C$ " subject-language integrated learning, namely: "content" (content) - stimulating the process of assimilation of knowledge and development of skills; "Communication" (interaction/communication) - enabling the process of using the acquired knowledge, skills, and abilities to gain knowledge on the issue; "Cognition" (cognitive orientation) - the development of the mental activity, reasoning of learners for a better understanding of the language and the subject; "Culture" (knowledge of cultural studies) - understanding the peculiarities of the culture of your country and other individual cultures, it contributes to the versatile socio-cultural development of the individual and effectively socializes it in a modern multicultural society (Content and Language Integrated Learning (CLIL) at School in Europe).

The methodology developed by us assumes the presence of such a tool as: "Workbook" (Figure two), which consists of several parts:

- "Introduction" to the topic of the lesson,

- "Main part," 


\section{Arab World English Journal (AWEJ) Special Issue on Covid 19 Challenges April 2021}

The Development of Intercultural Competence of Secondary School

Krotik \& Morhun

- "Mental map" task-reflection.

Figure two. "Workbook" for $9^{\text {th }}$ grade

Each participant of the educational process receives detailed instructions for working with the "Workbook."

Introduction to the topic of online classes begins with the guidelines, pupils/students undergo precise control of the teacher - facilitator, who does not announce any topic, goals, or objectives of the lesson. The teacher promotes learners' independent work, activates their critical thinking, which allows identifying and detailing the planned educational process at the initial stage of the class.

During a specific lesson, all learners do the required exercises and tasks in the second part of our "Workbook," named the "Main Part," in pairs or micro-groups of 3-5 participants. The lessons are made taking into account all components of our Model, enabling the formation of linguistic and cultural (English and Chinese) competence of the secondary school pupils/university students.

The third, final part of the developed training copy includes exercises for independent work in the "online" mode, which have a complicated level. The students will receive the highest or incentive scores by completing this part.

The peculiarity of the developed instruction for each of the participants is based on the empirical results of our previous research and both in individual and other types of work.

It is stated in the article above that we have identified four types of students with the appropriate representative system. Therefore, the audile needs to listen to the teacher or audio recording (or a member of the group) while reading the text, to write new foreign vocabulary, which he/she hears, and guess its meaning. The facilitator must set assignments according to students' representative type.

Visuals, kinesthetic, and digitals respond to inner and outer feelings, so while perceiving new material, high school students and first-year undergraduate students demonstrating these sensory channels need to be offered the exercises that affect the full range of bodily perceptions. For example, it is essential to see and feel the information provided on the symbolic and physical levels when working with the tasks of the first part. That is why we recommend the functions as follows:

- to read the text for the whole group;

- to arrange pictures for the reader in groups;

- to number the pictures in chronological order according to the content of the received information, etc. (Krotik, 2020).

While working on the second part, "Main part," we offer to imagine yourself as the main character in role-playing games/dialogues.

Working on the "Mental Map" and the digitals in the third practical part of our Workbook, all the above sensory channels actively cooperate, even online. During this 


\section{Arab World English Journal (AWEJ) Special Issue on Covid 19 Challenges April 2021}

cooperation, the students get the knowledge that meets both linguistic and cultural competence, and their age-leading needs, according to Vygotsky (2003). The researcher determined that the leading activity of adolescents is interpersonal communication with peers, so the form of learning that motivates action should involve interacting and communication in pairs, or microgroups, or small and large groups /classes; different quests, competitions, lessons-conferences, lessons-colloquia with elements of reflection are desirable too (Krotik, 2020).

Let us consider structurally, as an example, one of the topics of our proposed Model aimed at developing of linguistic and cultural (English) competence of our respondents on the current case "COVID-19 pandemic in Ukraine". That is expanded the issue within situational communication of the several problems, thus integrating several subjects: "Health Protection" and "Occupational Health."

I. "Introduction" to the lesson's topic (Figure three).

The introduction to lesson topic's is under the precise control of the teacher-facilitator (according to our methodological recommendations). $\mathrm{He} / \mathrm{she}$ does not announce any issues, goals, or objectives of the lesson; thus, the task of the first part of the workbook is not only to introduce new linguistic (English) knowledge on the topic. It is also aimed at actualizing the pupils'/students' independent work that activates their intuition, critical thinking, which allows us to determine and independently detail the planned educational process at this stage, basing on their life experience (key competence).

All students with the foremost leading sensory channel of information perception should be active in performing the exercises of the first part because, in the discussion, each of the participants expresses his/her thoughts on defining the topic, goals, and

Task 1 | Introduction:

1.1. Look at the photos and complete the captions with the correct words or word combinations.

1.2. Guess and write down the topic of the lesson according to the photos:

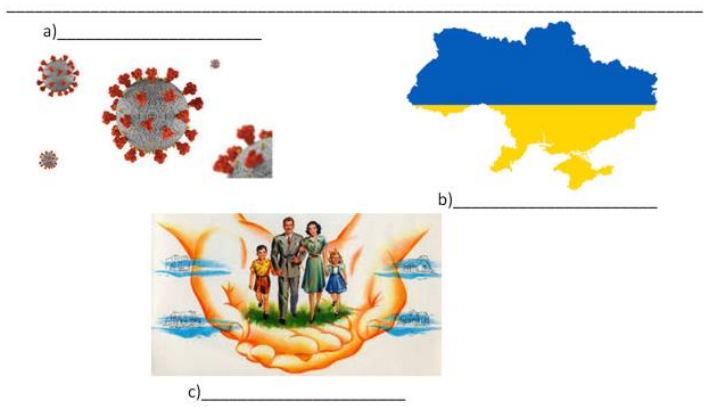

Figure three. "Workbook" for 9-th grade

"Introduction" objectives of the lesson. After all, the vision can be similar or different; thus, the ideas are supplemented in such a way (Krotik, 2020).

II. "Main part" (Figure four).

During the work on the exercises of the second (central) part of our workbook, pupils (students) develop their knowledge, skills, and abilities in these speech activities:

- speaking (monologues or dialogues, if they dispute);

- listening (they listen to the partner);

- writing (they write words/phrases/word combinations/short expressions, sentences);

- reading (they read what is written in the workbooks). 

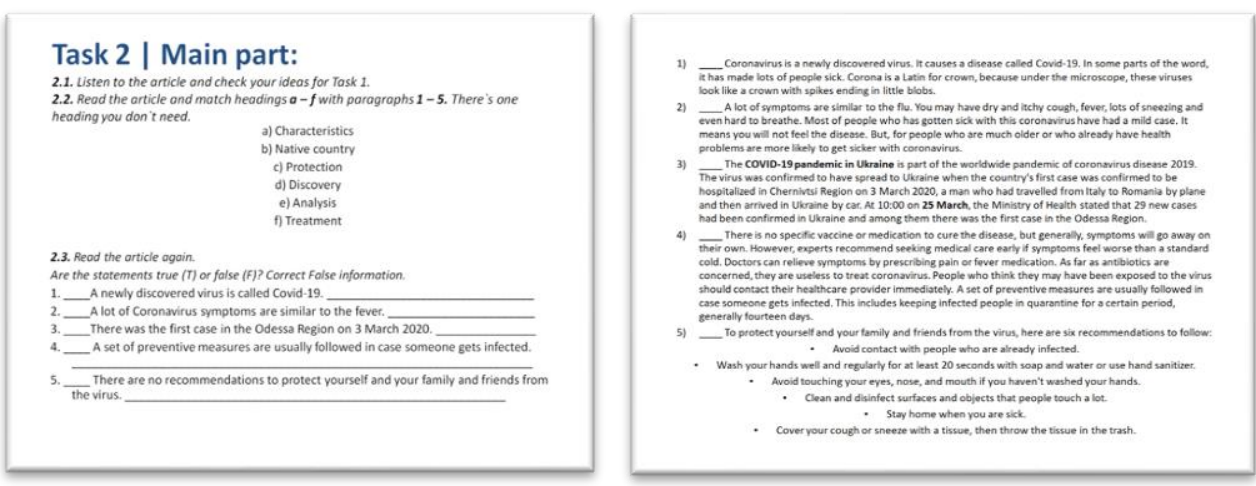

Figure four. "Workbook." "Main part."

Listening technology is implemented either with audio media (CD recording; flash drive; links via audio files of Google disk, etc.). If there are no technical teaching aids (TTA), the teacher reads the proposed text.

We involve the pupils/students in students' systematic and consistent work with authentic learning material, according to the "European Recommendations on Language Education," to ensure the mastery of normative communication. The number of lexical units increases, including those which contain a socio-cultural component, contribute to the effective formation of the competence under study. The exercises of the second part of our "Workbook" are aimed at systematization and generalization of lexical units, acquired during their previous work with the "Workbook."

At the stage of acquaintance and work "with new linguistic units (at the preparatory stage aimed at the formation of linguistic skills (Sydorenko, 2017), a verbal system of a foreign language in the form of the concept of this system alongside the rules of its use are formed; perception and comprehension of new lexical units are realized through their semanticization. Possible ways of semanticization are: performed through making up a story, a conversation, individual situations, independent acquaintance with a word (reading or listening to the text)" (Shatylov, 1977). The second section of the "Main part" of our "Workbook" includes exercises intended to develop reproductive skills of using lexical units.

Reproductive speech speaking skills are the basis for all types of language activities, so you should develop linguistic and cultural skills during listening, speaking, reading, and writing. All the recommendations and requirements are taken into account while formulating tasks by our Model. It is aimed at the formation of linguistic and cultural (English and Chinese) competence.

III. Reflection: "Mental map" (Figure five).

Reflection can be done both orally and in writing. An analysis of the pedagogical and methodological literature has shown that many scholars note that written examination is more Arab World English Journal www.awej.org 258 ISSN: 2229-9327 


\section{Arab World English Journal (AWEJ) Special Issue on Covid 19 Challenges April 2021}

important and useful for personality development. There are several well-known and most commonly used forms of written test, for example: essays, portfolios, logbooks, cinquains, diaries, and so on. We offer "Mental Map" as a type of written reflection (Naidova). The most critical condition in working with the "Mental Map" is its constant use during each lesson. Only then will this map help the learners to study more quickly and the teachers-to teach better. The "Mental map" is a so-called algorithm of reasoning and proof-giving. The focus is not on memorizing or reproducing information but on the content, reflection, sense, awareness of dependencies, and connections. Students can complete such a map throughout each lesson, or they can complete it at home by adding any additional material. It can be such as drawings, diagrams, etc.

However, we support the concept that the informatization of Ukrainian education is one of the most essential modernization processes of the modern education system. In particular, in the context of the COVID-19 pandemic, it is thanks to modern technologies, namely information. The educational paradigm is improved, new perspectives for increasing efficiency of the educational process are revealed. Currently, a significant role is given to self-education and distance education programs.

The studies of most Ukrainian and foreign scholars in the field of teaching English deal with the issues related to the problems of forming secondary school pupils' and university students' intercultural competence using English a foreign language, not Chinese. The language educators emphasize the necessity of combining language learning with the familiarization of learners with the culture of native speakers (which is reflected in educational nationally-marked texts). Unfortunately, there is nearly no corresponding research in teaching Chinese to secondary school pupils and university students; the issue regarding the selection of educational material and methods for implementing the educational process in the linguistic and cultural studies aspects is not exact either. In the view of the above, we could state that there is a need to perceive the Chinese language not as a purely lexical-grammatical-ideographic aggregate but as a holistic, integrated system. It has accumulated and evolved for millennia being, based on the philosophical and pedagogical heritage of China, its histories, everyday rituals, folklore, spiritual and moral treasure, ethnography, traditions of many generations. These elements can intertwine with the Ukrainian cultural heritage and contribute to the improvement of foreign language classes.

We support Oleksandra Popova's idea (Popova, 2020) that an essential place in the designated approach to the formation of secondary school pupils' linguistic and cultural competence in the process of studying the Chinese language belongs to the selection of the national and precedential material, which the scholar specifies as follows: "fables; artistic and ethnographic texts; ethnically-marked words, phraseologisms; historical and ethnographic works; reference texts about rituals, customs, everyday cultural life of representatives of native and foreign countries; texts are containing information about their beliefs, religious preferences; ethical and aesthetic literature of a national character, etc.); the above educational samples are to be creatively analyzed, synthesized, transformed into a curriculum” (Popova, 2020, p. 31).

Thus, we can assume that the linguoculturological approach to the formation of secondary school pupils' and university students' linguistic-and-cultural competence in studying 
the Chinese language can be associated with the concentration of pupils' attention on the study and descriptive analysis of China's and Ukraine's cultures. Philosophical phenomena used in foreign (Chinese) and state/national (Ukrainian) languages are actualized in the Chinese/Ukrainian language communicative-cognitive discourse.

\section{Conclusion}

According to the presented model, we define the English/Chinese linguistic and cultural competence of secondary (high school) pupils and university bachelor-course students is the ability and willingness of the individual to intercultural communication. We associate it with the term "intercultural competence." The online methodology takes into account the leading essential components of the NUS, the Common European Framework of Reference for Languages; modern pedagogical, psychological, and methodological innovation-integrated principles of organization of the educational process based on postulates of partnership pedagogy, child (student) -centrism, positive, age-related (developmental) and cognitive psychology; sub-competence-based and activity-center competence approaches, the subjectlanguage integrated principle of learning and the direction of continuity of education. The presented model of the online methodology attempts to resolve the contradiction between the rapid technical and technological development of an individual in ontogenesis. The gradual decline of his/her intercultural (English and Chinese) competence, as well as the restrictive conditions of the coronavirus pandemic, are to be considered. Modern and trendy topics are offered to the participants of the educational process to get acquainted with while learning English and Chinese. For the first time, the "Workbook" has been developed for training teachers/facilitators with corresponding instructions for use and guidelines. The effectiveness of the proposed methodology was experimentally proved, and we are going to consider ways of its improvement in our further studies.

\section{About the Authors:}

Kateryna Volodymyryvna Krotik is a Postgraduate of the Faculty of Foreign Languages, South Ukrainian National Pedagogical University named after K. D. Ushynsky. Her research interests include providing and teaching Theory and Methods of Teaching English (Germanic Languages; Oriental Languages; the Ukrainian language) to future teachers of English language and secondary school pupils; ORCID: https://orcid.org/0000-0002-3446-0246

Oleksandra Oleksandrivna Morhun is a Postgraduate student of the Department of Pedagogy, South Ukrainian National Pedagogical University named after K. D. Ushynsky. Her research interests in teaching Chinese and English to future university students`. ORCID: https://orcid.org/0000-0002-2078-4450

\section{References}

Al-Nofaie, H. (2020). Saudi University Students' Perceptions towards Virtual Education During Covid-19 Pandemic: Case Study of Language Learning via Blackboard. Arab World English Journal, 11 (3) 4-20. DOI: https://dx.doi.org/10.24093/awej/vol11no3.1.

Artemova V. (2006). History of pedagogy of Ukraine. Kyiv: Lybid.

Bekh I. (2000). The Personality-oriented approach in education. Vocational education: pedagogy and psychology: Ukrainian-Polish Yearbook, Kyiv: Chenstokhova. 
Arab World English Journal (AWEJ) Special Issue on Covid 19 Challenges April 2021

Bogush A. M. (2008). Formation of language personality at different age stages. [monograph] / Ed. Acad. Odesa.

Bondarevskaia E. (1999). Pedagogy: personality in humanistic theories and educational systems]. Rostov-on-Don: Bondarevskaia E.

Bulakh I.S. (2016). Psychology of adolescent personal growth: realities and prospects. Vinnytsia: TOV "Ninland-LTD."

Cognitive Psychology. Available at: https://en.wikipedia.org/wiki/Cognitive_psychology.

Content and Language Integrated Learning (CLIL) at School in Europe Available at: http://ec.europa.eu/languages/docum ents/studies/clilat-school-ineurope_en.pdf.

Definition and Selection of Competences. (2002). Theoretical and Conceptual Foundations (DESECO). Strategy Paper on Key Competences. An Overarching Frame of Reference for an Assessment and Research Program - OECD (Draft).

Developmental psychology Available at: https://en.wikipedia.org/wiki/Developmental psychology.

Dychkivska I. M. (2004). Innovative pedagogical technologies. Kyiv: Akademvydav.

Goncharenko S. U. (1997). Ukrainian pedagogical dictionary. Kyiv: Lybid.

Ivanchuk M. G. (2004) Fundamentals of integrated learning technology in primary school: teaching method. - Chernivtsi: Ruta.

Khutorskiy A. V. (2003). Key competences as a component of the personality-oriented paradigm of education, Public education. No. 2.

Kontseptsiia NUSh [NUS concept]. (n.d.) Available at: https://mon.gov.ua/ua/tag/novaukrainska-shkola.

Kremen V. G. (2009). Why education in Ukraine needs structural changes. "Den" - Daily allUkrainian newspaper "Day," 210(3130), 1-6.

Krotik Kateryna (2020). Methods forming modern English-language linguistic and cultural competence of secondary school students. Available at: https://drive.google.com/file/d/11utjojUD_Yimio5nB2t1di3DMDIQ91YG/view.

Kvas O. (2011). Child-centeredness in the sciences of education: historical aspect: [monograph]. Drogobych: Redaktsiino-vydavnychyi viddil Drogobytskogo derzhavnogo pedagogichnogo universytetu imeni Ivana Franka.

Law on Education (2017). Kyiv. Available at:https://www.venice.coe.int/webforms/documents/ default. aspx?pdffile=CDLREF(2017)047-e.

Law on Higher Education (2019). Kyiv. Available at: https://zakon.rada.gov.ua/laws/show/155618\#Text.

Naidonova A.V. Intelligence maps as a tool for practical work with information. Available at: http://ru.calameo.com/read/004373434dec4e2bf2b83.

Ministry of Education and Science of Ukraine. (2017). Foreign language curricula for secondary schools and specialized schools with in-depth study of foreign languages Grades 5 - 9: English, German, French, Spanish. (n.d.) Available at: https://mon.gov.ua/storage/app//media/zagalna \%20serednya/programy-5-9-klas/programi-inozemni-movi-5-9-12.06.2017.pdf

Nikolaieva S. U. (2013). Methods of teaching foreign languages and cultures: theory and practice: a textbook for students. classical, pedagogical, and linguistic universities. Kyiv: Lenvit. 
Arab World English Journal (AWEJ) Special Issue on Covid 19 Challenges April 2021

Organization of distance learning (2020) Kyiv. Available at:https://mon.gov.ua/ua/npa/shodoorganizaciyi-distancijnogo-navchannya;

Ovcharuk O. (2004). Competence approach in modern education: world experience and Ukrainian prospects: Library of educational policy. Kyiv

Ovsiienko L. (2013) The essence of the concepts "competence," "competence," "competence approach," "quality of education" in the light of the modern educational paradigm. Available at: http://nvd.luguniv.edu.ua/archiv/NN22/13olmsop.pdf

Pekhota O. (2005). Personality-oriented learning: teacher training. Mykolaiv.

Pidlasyi I. P. (2010). Produktyvnyi pedagog. Nastilna knyga vchytelia [Productive teacher. Teacher's desk book]. Kharkiv: Vyd. grupa "Osnova."

Popova O. V. (2016). Professional-speech training of future translators of the Chinese language in terms of university education: [monograph] - Odesa: South Ukrainian National Pedagogical University named after KD Ushinsky; Odesa City Printing House.

Popova O. V., Jin Julu. (2020). Linguocultural competence of primary school pupils studying at secondary schools as a methodological problem (based on the Chinese language) [monograph] - Odesa: South Ukrainian National Pedagogical University named after KD Ushinsky; Odesa.

Positive psychology. Available at: https://en.wikipedia.org/wiki/Positive_psychology.

Proshkin V. V. (2010). Integration of university science and education: historical aspect. Ejournal "Pedagogical Science: History, Theory, Practice, Development Trends."- №2. Available at: http://intellect-invest.org.ua/pedagog_editions_e-magazine_pedagogical_s.

Rychen S. \& Tiana A. (2004). Developing Key Competences in Education: Some Lessons from International and National Experience, Geneve: UNESCO-IBE, Studies in Comparative Education.).

Sait Vydavnycha grupa “Osnova.” (2005). Refleksiia [Osnova Publishing Group website. Reflection].http://osnova.com.ua. Available at: http://osnova.com.ua/news/657-\%D0\%A0\% D0\%B5\%D1\%84\%D0\% BB\%D0\%B5\%D0\%BA\%D1\%81\%D1\%96\%D1\%8F.

Shatylov C. F. (1977). Metodyka obucheniia nemetskomu yazyku v srednei shkole [Methodology for teaching German in secondary school].

Spector, J. Michael de la Teja, Ileana. (2001). ERIC Clearinghouse on Information and Technology Syracuse NY. Competences for Online Teaching. ERIC Digest. Competence, Competences, and Certification.

State standard of basic and complete general secondary education / Resolution of the Cabinet of Ministers of 23.11.2011 № 1392]. (n.d.) Available at: http://zakon1.rada.gov.ua /laws/ show.

Sydorenko Victoria. (2018). Professional media competence development for teachers of foreign languages using continuing education courses: theoretical principles Association agreement from partnership to cooperation collective monograph / Victoria Sydorenko, Artemy Ponomarevskyi. - Accent Graphics Communication Publishing, Hamilton, Ontario.

Sydorenko V. V. (2017). New Ukrainian school: conceptual guidelines/materials of the methodological seminar with online broadcast "Educational and philosophical principles of the New Ukrainian school". Kyiv, Available at: http://lib.iitta.gov.ua/708457/.

Decree of the President of Ukraine (2002). "About the National Doctrine development of education” №347/2002 Available at:https://zakon.rada.gov.ua/laws/show/347/2002\#Text.

Ushynskyi K. D. (1954). Person as a subject of education. Kyiv: Derzh. Educational department. Vygotskyi L. S. (2003). Child developmental psychology. Moscow: Eksmo. 
Vyshnevskyi O. (2006). Theoretical foundations of modern Ukrainian pedagogy: A guide for students of higher educational institutions. Drogobych: Kolo.

Zagalnoievropeiski Rekomendatsii z movnoi osvity: vyvchennia, vykladannia, otsiniuvannia [Pan-European Recommendations for Language Education: Study, Teaching, Assessment]. (n.d.) Available at: https://lenvit.ucoz.ua/ZER.pdf.

Zakharenko I. V. (1997). Vestnik series 9: Philology. Kohnityvna Baza i Pretsedentni Fenomenym Systemi Inshykh Odynyts i Komunikatsii // Moscow. 142 p.

Zymniaia I. (1997). Pedagogicheskaia psykhologiia [Pedagogical psychology]. Rostov-na-Donu: "Feniks"

Zimnya I. A. (2003). Key competences - a new paradigm of the result of education. Higher education today. No. 5 . 